\title{
Facilitating Sounds in Indonesian
}

\author{
Praptomo Baryadi Isodarus \\ praptomo@usd.ac.id \\ Indonesian Literature Study Program, Universitas Sanata Dharma
}

\begin{abstract}
This article presents the research result of facilitating sounds in Indonesian. Facilitating sound is a sound which facilitates the pronunciation of a sound sequence in a word. Based on the data

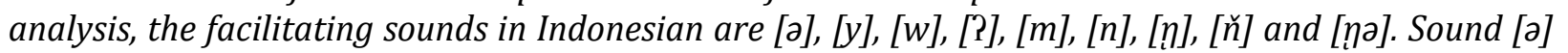
facilitates the consonant cluster pronunciation in a word. Sound [y] facilitates the pronunciation of the sound sequences [ia] and [aia] among syllables and morphemes. Sound [w] facilitates the pronunciation of sound sequence [ua] among syllables and morphemes and the sound sequence of [oa] and [aua] among morphemes. Sound [?] facilitates the sound sequence [aa] among syllables and morphemes and the sound sequence [oa] among syllables. Sound [m] facilitates the pronunciation of nasal sound sequence [N] in prefixes me $(N)$ - or pe $(N)$ - whose morpheme base begins with sounds [b, $p, f, v]$. Sound [ $n]$ facilitates the pronunciation of sound sequences [d] and [t] in the beginning of the morpheme base. Sound [n] facilitates the pronunciation of sound sequence [N] in prefixes me $(N)$ - or pe(N)- whose morpheme base begins with the vowels [a, i, u, e, a, $\varepsilon, o, 0],[g]$, [h] and [k]. Sound [ň] facilitates the pronunciation of sound sequence [N] in prefixes me $(N)$ - or pe(N)- whose morpheme base begins with sounds of [j, $c, s]$. Sound [n] facilitates the pronunciation of words which are formed by prefixes me $(N)$ - or pe(N)- with one syllable morpheme base.
\end{abstract}

Keywords: facilitating sound, phonology, Indonesian

\section{Introduction}

This study discusses facilitating sound in the Indonesian. Facilitating sound is a sound that serves a function to facilitate a sequence of sounds in a word. For example, among the sequence of sounds [aa] in the word saat 'moment' has a facilitating sound [?]. The real pronunciation of a word saat 'moment' is [sa?at]. The sound of [?] facilitates the pronunciation of a sequence of sounds [aa]. Another example is among the sequence of sounds [ia] in the word siang 'afternoon' in which a facilitating sound [y] can be heard. The pronunciation of the word siang 'afternoon' is [siyang]. The sound of [y] facilitates the pronunciation of the sequence of sounds [ia].
In the oral language, facilitating sound can be identified by the listener. In a written language, facilitating sound is not always described in the form of orthographic alphabet. For example, the facilitating sound [?] in the word saat 'moment' [sa?at] and the facilitating sound [y] in of the word siang [siyang] 'afternoon' are not described in the form of alphabets.

In this paper, facilitating sound in Indonesian is discussed in two aspects. First, what sounds are the facilitating sounds in the Indonesian? Second, what sequence of sounds can be facilitated by the facilitating sound in the Indonesian language? This article will analyze the answers to both questions completely. 
The answers to both questions are important for Indonesian speakers to pronounce the sequence of sounds fluently, and to identify where the presence of certain sounds is required. In addition, the answers also remind the language researchers, especially researchers in Phonetics and Phonology to use the oral language as the primary data even though the language studied is familiar with the written language so that the oral language features can be fully identified.

\section{Literature Review}

The specific discussion on the facilitating sound in Indonesian has not found yet in books of the phonology of Indonesian. The books are generally limited to describe every sound and phoneme in Indonesian. As a matter of fact, most of the Phonology books in Indonesian do not explain the facilitating sound through the data of phonetic transcription. For example, in the phonology book by Aminoedin (1984), the words biasa 'orbinary', tiap 'each', kemudian 'then' and giat 'active' are transcribed phonetically into [biyasa], [tiyap], [kəmudiyan] and [giyat]. There is a facilitating sound [y] on the vowel sequence of sounds [ia] in the phonetic transcription. The absence of the facilitating sound in the phonetic transcription of words containing the facilitating sound can be speculated that all of the data in the phonology books are not based on the oral language.

In several books of Indonesian morphology by Ramlan (1983), Kridalaksana (1989), Arifin (2007), Chaer (2008) and Muslich (2008), morpho-phonemic in Indonesian is discussed. Morpho-phonemic refers to a phonological change in the morpheme due to the assemblage among morphemes (Baryadi, 2011: 28). There are a number of affixes having a phonological change due to their interaction with the morpheme base. Various phonological changes on several affixes in Indonesian have been described in several books of Indonesian morphology. However, the functions of the phonological changes in facilitating the pronunciation of sequence of sounds in a word have not been explained. It is because the functional approach in analyzing words formation has not been applied in several books of Indonesian morphology. The common approaches used in several books of Indonesian morphology are structural approach and process approach. Nevertheless, the result of morpho-phonemic studies in several books of Indonesian morphology has great contribution in identifying the facilitating sound in Indonesian. Moreover, the book by Kridalaksana (1989) more completely describes the types of the changes of sounds in affixes in Indonesian due to the assemblage between affixes and morpheme bases.

\section{Theoretical Framework}

This section addresses the basic concepts used to discuss the facilitating sound in Indonesian. Facilitating sound is a sound that serves a function to facilitate a sequence of sounds in a word. The sequence of sounds is two or more sounds that line up linearly in a word. The sequence of sounds in Indonesian consists of three consonant clusters, consonant sequence and vowel sequence. "Consonant cluster is a sequence of two or more consonants recognized as the same syllable. A sound [pr] in the word praktik 'practice' is a consonant sequence. The consonant sequence is also found in sounds [pl] in the word plastik 'plastic', [tr] in the word sastra 'literature', [str] in the word struktur 'structure' (Alwi et.al., 2003: 52-53). A consonant cluster is different from a consonant sequence. The consonant sequence is a sequence of two or more consonants recognized as a different syllable. The examples of consonant sequence are [mb] in the word gambar [gambar] 'picture', whose sound [m] is in syllable gam- [gam-] and sound [b] is in syllable -bar [-bar].

The vowel sequence is two vowels lining up in a different syllable (Alwi et.al., 2003: 62-63). The examples of the vowel sequence are [aI] in the word kain [kaIn] where the sound [a] is in syllable $k a-[\mathrm{ka}]$ and [I] is in syllable -in [-In]. Vowel sequence can be found among syllables such as sound [ai] in the word kaidah 'rule' and among morphemes such as the sounds [ua] in the word tujuan [tujuwan] 'aim' which means that the sound 
[u] is in the final morpheme of tuju \{tuju and sound [a] is in the initial morpheme of -an $\{-$ an\}. Vowel sequence is different from diphthong. Diphthong belongs to a vowel sound. Diphthong is in the same syllable. There are three diphthongs in Indonesian: /ay/, /aw/ and /oy/ which can be written into ai, au and oi (Alwi et.al., 2003: 62). An example of diphthong is the sound [ay] in the word sampai [sampay] 'arrived', [aw] in the word pulau [pulaw] 'island' and [oy] in the word spoi [spoy] 'spoi'.

\section{Research Method}

This research was conducted through three stages of language handling strategies proposed by Sudaryanto (2015: 6), namely data collection, data analysis and presentation of data analysis result. The implementation of each strategy was done by using certain methods.

This research object was the facilitating sound of the sequence sound pronunciation in Indonesian words. The collected data were words containing the facilitating sound in Indonesian. The data were collected from two sources, namely Indonesian used by the speakers orally and Indonesian used creatively by the writers in daily life. In the first source, the use of oral Indonesian becomes the data of conversations among students in campus. The data were obtained from the second source which is called introspection data (Botha, 1981:67). However, the data should be grammatically validated by other Indonesian speakers and Kamus Besar Bahasa Idonesia online or the official online Indonesian dictionary (2015).

The data collection from the first source was conducted using the listening method (Sudaryanto 2015: 203), which the researcher listens to the use of the language on the data source. The listening result was then recorded in the data card. The data collection from the second source was conducted using the intuitive method (Labov 1972: 9), by generating the researcher's language competence as the Indonesian speaker. In this case, the researcher is an internalist meaning that the researcher as the language speaker becomes a research respondent.
The data that had been collected were then classified based on the types of the sequence of sounds which becomes the place where the facilitating sound occur. After being classified, the data were analyzed by using equivalent articulatory phonetic method and sharing method which used interruption method as the interruption method and deletion method (2015). The types of facilitating sound can be determined based on the utterance produced by using the equivalent articulatory phonetic method. The interruption technique is applied by inserting certain sounds in the certain sequence of sounds. The deletion technique is applied by deleting the facilitating sound from a certain sequence of sounds. Those techniques were used to prove the fluency of the pronunciation of the certain sequence of sounds.

The data analysis was conducted using various techniques and methods which produced rules of the use of the facilitating sound in Indonesian. The rules of the use of the facilitating sound in Indonesian are presented in two ways: by a formulation in the form of sentences, diagrams and symbols. The first formulation of the linguistic rules is called informal (Sudaryanto 2015: 241) or verbal method, while the second formulation is called formal method (Sudaryanto 2015: 241) or visual method. From those methods, the informal method was the main presentation method of this research. The formal method was used to strengthen the informal method. The formal method is used to make the linguistic rules visible so that the readability is high (Baryadi Isodarus 2000: 160).

\section{Discussion}

Based on the data analysis, the sounds that belong to the facilitating sounds are [ə], [y], [w], [?], [m], [n], [n], [ň], dan [nə]. The use of every facilitating sound is discussed below.

\section{The Facilitating Sound [ə]}

There is no word containing a consonant cluster in Indonesian. Words that belong to consonant cluster are cognate words from local or foreign language. There is no consonant cluster that makes Indonesian 
speakers difficult to pronounce it. Therefore, to simplify the pronunciation, the sound of [ə] is often inserted with the consonant cluster. The examples are as follows:
(1) krupuk [kərupUk] 'creckers'
(2) kramas [kəramas] 'shampoo'
(3) blangko [bəlayko] 'blank'
(4) proses [pəroses] 'process'
(5) strategis [sətrategis] 'strategic'
(6) skala [səkala] 'scale'
(7) status [sətatus] 'status'
(8) prangko [pərayko] 'stamps'

Several words contain the consonant cluster that comes from Javanese. The consonant cluster is inserted with letter ' $e$ ' or sound [ə] after the words become cognate words into Indonesian. For example, trampil [trampil] 'skilled', prawan [prawan] 'virgin' and prabot [prabst] 'furniture' to be terampil [terampil] 'skilled', perawan [pərawan] 'virgin' and perabot [pərabst] 'furniture'.

\section{The Facilitating Sound [y]}

Sound [y] is used to facilitate the sequence of sounds of [ia] and [aia] among syllables or morphemes. Below are the examples of sound [y] that facilitates the pronunciation of the sequence of sounds among syllables.

(9) ia [iya] 'she/he'

(10) ialah [iyalah] 'is'

(11) dia [diya] 'she/he'

(12) pria [priya] 'man'

(13) siapa [siyapa] 'who'

(14) dunia [duniya] 'world'

(15) mulia [muliya) 'noble'

(16) diam [diyam] 'silent'

(17) tiang [tiyang] 'pole'

(18) liar [liyar] 'wild'

Sound [y] is also used to facilitate the pronunciation of the sequence of sounds [ia] among morphemes, which is the morpheme base ending with the sound of [i] followed by suffix \{-an\} (Ramlan 1983: 84; Kridalaksana 1989: 185).

(19) huni + -an to be hunian [huniyan] 'shelter'
(20) tari + -an to be tarian [tariyan] 'dance'

(21) bagi + -an to be bagian [bagiyan] 'part'

(22) pe- + lari + -an to be pelarian [pəlariyan] 'escape'

(23) per- + kelahi + -an to be perkelahian [pərkelahiyan] 'fights'

(24) per- + tani + -an to be pertanian [pərtaniyan] 'agriculture'

(25) per- + hati + -an to be perhatian [pərhatiyan] 'attention'

(26) ke- + ahli + -an to be keahlian [kəahliyan] 'skill'

(27) ke- +abadi + -an to be keabadian [kəabadiyan] 'eternity'

(28) ke- + suci + -an to be kesucian [kəsuciyan] 'holiness'

Sound [y] is used to facilitate the pronunciation of the sequence of diphthong sound [ai] followed by vowel [a] among morphemes whose base ends with sound [ai] and suffix \{-an\} (Ramlan 1983: 84; Kridalaksana 1989: 185). Here are the examples.

(29) urai + -an to be to be uraian [uraiyan] 'description'

(30) buai + -an to be buaian [buaiyan] 'crib'

(31) untai + -an to be untaian [untaiyan] 'strand'

(32) semai + -an to be semaian [səmaiyan] 'crops'

(33) tuai + -an to be tuaian [tuaiyan] 'haervest'

(34) ke- + damai + -an to be kedamaian [kedamaiyan] 'peace'

(35) ke- + sampai + -an to be kesampaian [kesampaiyan] 'taken'

(36) ke- + pandai + -an to be kepandaian [kepandaiyan] 'ingenuity'

(37) ke- + ramai + -an to be keramaian [keramaiyan] 'crowd'

Sound $[y]$ can be either used or not to facilitate the pronunciation of sound sequence [ia] on prefix $\{d i-\}$ followed by morpheme base beginning with the sound of [a]. Here are the examples. 
(38) di + ambil to be diambil [diambil/diyambil] 'taken'

(39) di + angkat to be diangkat [diangkat/diyangkat] 'lifted'

(40) di + antar to be diantar [diantar/diyantar] 'escorted'

(41) di + adakan to be diadakan [diadakan/diyadakan] 'held'

(42) di + angkut to be diangkut [diangkut/diyangkut] 'transported'

(43) di + arak to be diarak [diarak/diyarak] 'paraded'

\section{The Facilitating Sound [w]}

Sound $[w]$ is used to facilitate the sound sequence [ua] among syllables and morphemes and [ua], [oa] and [aua] among morphemes. Below are examples of the use of sound $[\mathrm{w}]$ as the facilitating sound of the sequence sounds of [ua] among syllables.

(44) tua [tuwa] 'old'

(45) dua [duwa] 'two'

(46) buah [buwah] 'fruit'

(47) tuan [tuwan] 'master'

(48) ruang [ruwang] 'space'

(49) buang [buwang] 'discard'

Sound $[w]$ is used to facilitate the pronunciation of the sound sequence [ua] in relation among morphemes whose base ends with sound $[\mathrm{u}]$ and suffix of $\{-\mathrm{an}\}$ (Ramlan 1983: 84; Kridalaksana 1989: 185). Here are the examples:

(50) tuju + -an to be tujuan [tujuwan] 'purpose'

(51) satu + -an to be satuan [satuwan] 'unit'

(52) bantu + -an to be bantuan [bantuwan] 'aid'

(53) per- + jamu + -an to be perjamuan [pərjamuwan] 'banquet'

(54) ke - + satu + -an to be kesatuan [kəsatuwan] 'unity'

[55] pem- + baru + -an to be pembaruan [pəmbaruwan] 'renewal'

Sound $[w]$ is used to facilitate the pronunciation of sound sequence [oa] in relation among morphemes, whose base ends with sound [o] and suffix $\{-a n\}$ (Kridalaksana 1989: 185). Here are the examples:

(56) per- + plonco + -an to be perploncoan [pərploncowan] 'initiation'

(57) per- + toko + -an to be pertokoan [pərtokowan] 'shops'

Sound [w] is also used to facilitate the pronunciation of sound sequence [aua] in relation among morphemes, whose base ends with diphthong [au] and suffix $\{-a n\}$ (Kridalaksana 1989: 185). Here are the examples:

(58) himbau + -an to be himbauan [himbauwan] 'appeals'

(59) pantau + -an to be pantauan [pantauwan] 'monitory'

(60) perantau + -an to be perantauan [pərantauwan] 'oversights'

(61) pe(N)- + hijau + -an to be penghijauan [pənghijauwan] 'greening'

(62) ke- + galau + -an to be kegalauan [kəgalauwan] 'turnoid'

\section{The Facilitating Sound [?]}

Sound [?] is used to facilitate the sound sequence of [aa] among syllables and morphemes and [oa] among syllables. The following examples are as follows:

(63) saat [sa?at] 'moment'

(64) taat [taPat] 'obidunce'

(65) manfaat [manfa?at] 'benefit'

Below are the examples of the use of sound [?] which has morpheme base ending with sound [a] and suffix $\{-a n\}$.
(66) per- + jumpa + -an to be perjumpaan [pərjumpa?an] 'encounter'
(67) per- + tanya + -an to be pertanyaan [pərtanya?an] 'questions'
(68) per- + nyata + -an to be pernyataan [pərnyata?an] 'statement'

The following examples show the use of sound [?] to facilitate the pronunciation of the sound sequence [oa] among syllables. 
(69) doa [do?a] 'prayers'

(70) soal [so?al] 'questions'

\section{The Facilitating Sound [m]}

Sound $[\mathrm{m}]$ is used to facilitate the pronunciation of a nasal sound in morphemes $m e(N)$ - and $p e(N)$ - whose initial sounds of the base are [b, p, f, v] (Ramlan, 1983: 74). Below are the examples of function of the sound $[\mathrm{m}]$.

(69) me(N)- + baca to be membaca [məmbaca] 'reading'

(70) me(N)- + bicarakan to be membicarakan [məmbicarakan] 'talking'

(71) me(N)- + panggil to be memanggil [məmangil] 'calling'

(72) me(N)-+ pasang to be memasang [məmasay] 'installing'

(73) me(N)- + paku to be memaku [məmaku] 'nailing'

(74) me(N)- + memfasilitasi to be memfasilitasi [məmfasilitasi] 'facilitating'

(75) me(N)- + fokus to be memfokus [məmfokus] 'focusing'

(76) me(N)- + foto to be memfoto [məmfoto] 'photographing'

(77) $\mathrm{me}(\mathrm{N})-+$ vakum to be memvakum [məmvakum] 'vacuuming'

(78) me(N)- + variasikan to be mamvariasikan [məmvariasikan] 'varying'

As shown in examples number (72), (73) and (74), sound [p] in the beginning of morpheme base will dissolve when it is approached by prefix $m e(N)$ - because sound [p] is voiceless. Here are the examples.

(79) pe(N)- + baca to be pembaca [pəmbaca] 'reader'

(80) pe(N)- + bahas to be pembahas [pəmbahas] 'discussor'

(81) pe(N)- + bicara to be pembicara [pəmbicara] 'speaker'

(82) pe(N)- + pacu to be pemacu [pəmacu] 'booster'

(83) pe(N)- + panah to be pemanah [pəmanah] 'archer'

(84) pe(N)- + pasang to be pemasang [pəmasang] 'mounter'
(85) pe(N)- + fokus to be pemfokus [pəmfokus] 'to make a focus'

(86) pe(N)- + foto to be pemfoto [pəmfoto] 'photographer'

(87) pe(N)- + vakum to be pemvakum [pəmvakum] 'vacuumer

(88) pe(N)- + vaksin to be pemvaksin [pəmvaksin] 'vaksin'

The examples number (82), (83) and (84) shows that sound [p] in the beginning of morpheme base will dissolve when it is approached by prefix $m e(N)$ - because sound $[p]$ is voiceless.

\section{The Facilitating Sound [n]}

Sound [n] is used to facilitate the pronunciation of sound sequence $[\mathrm{N}]$ in prefixes me(N)- or $p e(N)$ - whose initial sound base are [d] and [t] (Ramlan 1983: 75). Here are the examples.

(89) me(N)- + darat to be mendarat [məndarat] 'landing'

(90) me(N)- + didik to be mendidik [məndidI?] 'educating'

(91) me(N)- + dadak to be mendadak [məndada?] 'suddenly'

(92) me(N)- + dirikan to be mendirikan [məndirikan] 'establishing'

(93) me(N)- + duduki to be menduduki [mənduduki] 'occupying'

(94) me(N)- + tulis to be menulis [mənulIs] 'writing'

(95) me(N)- + tata to be menata [mənata] 'organizing'

(96) me(N)- + tanam to be menanam [mənanam] 'planting'

(97) me(N)- + tugaskan to be menugaskan [mənugaskan] 'assigning

(98) me(N)- + temani to be menemani [mənəmani] 'accompany'

In examples number (94), (95), (96), (97), and (98), sound $[t]$ in the beginning of a morpheme will dissolve when it is approached by prefix of me(N)- because sound $[t]$ is voiceless.

Below are the examples of the use of [n] to facilitate the pronunciation of sound sequence $[\mathrm{N}]$ in the beginning of prefix $p e(N)$ - 
whose initial sounds in the morpheme base are $[\mathrm{d}]$ and $[\mathrm{t}]$.

$$
\begin{aligned}
& \text { (99) pe(N)- + duduk to be penduduk } \\
& \text { [pəndudu?] 'population' } \\
& \text { (100) pe(N)- + didik + -an to be } \\
& \text { pendidikan [pəndidikan] } \\
& \text { 'education' } \\
& \text { (101) pe(N)- + tulis to be penulis } \\
& \text { [pənulis] 'writers' } \\
& \text { (102) pe(N)- + tulis + -an to be } \\
& \text { penulisan [pənulisan] 'writing' }
\end{aligned}
$$

The examples number (101) and (102) show that sound $[t]$ in the beginning of morpheme base will dissolve when it is approached by prefix $p e(N)$ - because sound of [t] is voiceless.

\section{The Facilitating Sound [n]}

In written language, the sound of [ $\mathrm{y}]$ is written as $n g$. Sound [ $y$ ] is used to facilitate the pronunciation that is formed by prefixes $m e(N)$ - or $p e(N)$ - with the beginning basic form of vowel sounds [a, i, u, e, ə, $\varepsilon, 0,5],[\mathrm{g}]$, [h] and [k] (Ramlan, 1983: 79). The examples are described as follows:

$$
\begin{aligned}
& \text { (103) me(N)- + atur to be mengatur } \\
& \text { [mənatur] 'regulating' } \\
& \text { (104) pe(N)- + atur to be pengatur } \\
& \text { [pənatur] 'regulator' } \\
& \text { (105) me(N)- + iris to be mengiris } \\
& \text { [məฺ̣irIs] 'slicing' } \\
& \text { (106) pe(N)- + iris to be pengiris } \\
& \text { [pənirIs] 'slicer' } \\
& \text { (107) me(N)- + urus to be mengurus } \\
& \text { [mə̣urUs] 'take car of' } \\
& \text { (108) pe(N)- + urus to be pengurus } \\
& \text { [pəॄฺurus] 'administrator' } \\
& \text { (109) me(N)- + ekor to be mengekor } \\
& \text { [mənekor] 'imitating' } \\
& \text { (110) pe(N)- + ekor to be pengekor } \\
& \text { [pəฑekor] 'imitator' } \\
& \text { (111) me(N)- + emban to be } \\
& \text { mengemban [mənemban] } \\
& \text { 'carrying' }
\end{aligned}
$$

(115) me(N)- + olah to be mengolah [məฺ̣olah] 'processing'

(116) pe(N)- + olah to be pengolah [pənolah] 'processor'

(117) me(N)- + obrol to be mengobrol [məฺฺjobrol] 'chatting'

(118) pe(N)- + obrol to be pengobrol [pəॄฺjobrol] 'blab'

(119) me(N)- + garis to be menggaris [məॄgarIs] 'lining'

(120) pe(N)- + garis to be penggaris [pə̣garIs] 'ruler'

(121) me(N)- + himpun to be menghimpun [məॄhimpUn] 'collecting'

(122) pe(N)- + himpun to be penghimpun [pəฺ̣himpun] 'gatherers'

(123) me(N)- + karang to be mengarang [mənaran] 'writing'

(124) pe(N)- + karang to be pengarang [pə̣aran] 'author'

The examples number (123) and (124) show that the basic form that begins with sound of [k] will dissolve when it is approached by prefixes $m e(N)$ - or $p e(N)$ - because sound of [k] is voiceless.

\section{The Facilitating Sound [ř]}

In written language, sound [ř] is shown as $n y$. The sound of [ [ $\mathrm{n}]$ is used to facilitate the pronunciation of words beginning with prefixes of $m e(N)$-or $p e(N)$ - whose morpheme base begins with sounds [j, c, s] (Ramlan 1983: 77). Here are the examples.

$$
\begin{aligned}
& \text { (125) me(N)- + jaga to be menjaga } \\
& \text { [məňjaga] 'keep' } \\
& \text { (126) pe(N)- + jaga to be penjaga } \\
& \text { [pəňjaga] 'guard' } \\
& \text { (127) me(N)- + curi to be mencuri } \\
& \text { [məňcuri] 'steal' } \\
& \text { (128) pe(N)- + curi to be pencuri } \\
& \text { [pəňcuri] 'thief' } \\
& \text { (129) me(N)- + sidik to be menyidik } \\
& \text { [məňidı?] 'investigating' } \\
& \text { (130) pe(N)- + sidik to be penyidik } \\
& \text { [pəňidı?] 'investigator' }
\end{aligned}
$$

The examples number (129) and (130) show that basic form that begins with sound [s] will dissolve when it is approached by prefixes 
$m e(N)$ - or pe(N)- because sound [s] is voiceless.

\section{The Facilitating Sound [nə]}

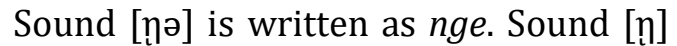
is used to facilitate the pronunciation of words beginning with prefixes me $(N)$ - or pe(N)- whose morpheme base contains one syllable (Ramlan, 1983: 83). Here are the examples.

$$
\begin{aligned}
& \text { (131) me(N)- + tik to be mengetik } \\
& \text { [məngətik] 'typing' } \\
& \text { (132) pe(N)- + tik to be pengetik } \\
& \text { [pəngətik] 'typist' } \\
& \text { (133) me(N)- + cat to be mengecat } \\
& \text { [məngəcat] 'paiting' } \\
& \text { (134) pe(N)- + cat to be pengecat } \\
& \text { [pəngəcat] 'painter' } \\
& \text { (135) me(N)- + pel to be mengepel } \\
& \text { [məngəpel] 'mopping' } \\
& \text { (136) pe(N)- + pel to be pengepel } \\
& \text { [pəngəpel] 'mopper' }
\end{aligned}
$$

\section{Conclusion}

Facilitating sound in Indonesian contains the pronunciation of consonant cluster, vowel sequence among syllables and morphemes, and sound sequence among morphemes. The facilitating sound the pronunciation of consonant cluster is sound [ə].

The facilitating sound of the pronunciation of a vowel sequence among syllables and morphemes are sounds [y, w, ?]. Sound [y] facilitates the pronunciation of the sound sequences [ia] and [aia] among syllables and morphemes. Sound [w] facilitates the pronunciation of the sound sequence [ua] among syllables and morphemes and also the sound sequences of [oa] and [aua] among morphemes. Sound [?] facilitates the sound sequence [aa] among syllables and morphemes and the sound sequence [oa] among syllables.

The facilitating sounds in the pronunciation of the sound sequence among morphemes are [m], [n], [n], [ň] and [nə]. Sound $[\mathrm{m}]$ facilitates the pronunciation of nasal sound [N] in prefixes me $(N)$ - or pe(N)whose morpheme base begins with sounds $[b$, $p, f, v]$. Sound [n] facilitates the pronunciation of sound sequences [d] and [t] in the beginning of the morpheme base. Sound [n] facilitates the pronunciation of sound sequence $[\mathrm{N}]$ in prefixes me $(N)$ - or pe $(N)$ whose morpheme base begins with [a, i, u, e, $\partial, \varepsilon, 0,5],[g],[h]$ and [k]. Sound of [ň] facilitates the pronunciation of the sound sequence $[\mathrm{N}]$ in prefixes of $m e(N)$ - or $p e(N)$ whose morpheme base begins with sounds $[\mathrm{j}$, c, s]. Sound [nə] facilitates the pronunciation of words formed by prefixes of $m e(N)$ - or $p e(N)$-, whose the morpheme base contains one syllable.

\section{References}

Alwi, Hasan; Soenjono Dardjowidjodjo; Hans Lapoliwa; Anton M. Moeliono. Tata Bahasa Baku Bahasa Indonesia. Edisi Ketiga. Jakarta: Balai Pustaka, 2003.

Aminoedin, A.; Soedjiatno; H.S. Razaq; I.L. Marsoedi; Taryono. Fonologi Bahasa Indonesia: Sebuah Tinjauan Deskriptif. Jakarta: Pusat Pembinaan dan Pengembangan Bahasa, Departemen Pendidikan dan Kebudayaan, 1984.

Arifin, Zaenal. Morfologi: Bentuk, Makna, dan Fungsi. Jakarta: Penerbit PT Grasindo, 2007.

Badan Pembinaan dan Pengembangan Bahasa. Kamus Besar Bahasa Indonesia. Dalam Jaringan, 2015.

Baryadi Isodarus, Praptomo. "Konstruksi Perurutan Waktu pada Tataran Kalimat dalam Wacana Bahasa Indonesia: Suatu Kajian tentang Ikonisitas Diagramatik". Disertasi Program Doktor. Yogyakarta: Universitas Gadjah Mada, 2000.

Baryadi, I. Praptomo. Morfologi dalam Ilmu Bahasa. Yogyakarta: Penerbit Universitas Sanata Dharma, 2011.

Botha, Rudolf P. The Conduct of Linguistics Inquiry: A Systematic Introduction to the Methodology of Generative Grammar. Mouton: The Hague, 1981. 
Chaer, Abdul. Morfologi Bahasa Indonesia (Pendekatan Proses). Jakarta: Penerbit PT Rineka Cipta, 2008.

Kridalaksana, Harimurti. Beberapa Prinsip Perpaduan Leksem dalam Bahasa Indonesia. Yogyakarta: Penerbit Kanisius, 1988.

Kridalaksana, Harimurti. Pembentukan Kata dalam Bahasa Indonesia. Jakarta: Penerbit PT Gramedia, 1989.

Labov, William. "Some Principles of Linguistic Methodology." Dalam Language and Society I. HIm. 97-120, 1972.

Muslich, Masnur. Tata Bentuk Bahasa Indonesia: Kajian Tata Bahasa Deskriptif. Jakarta: PT Bumi Aksara, 2008.

Ramlan, M. Morfologi: Suatu Tinjauan Deskriptif. Yogyakarta: UP Karyono, 1983.

Sudaryanto. Metode dan Aneka Teknik Analisis Bahasa: Pengantar Penelitian Wahana Kebudayaan secara Linguistis. Yogyakarta: Sanata Dharma University Press, 2015. 